\title{
Ghost Species: Spectral Geographies of Biodiversity Conservation
}

Shane McCorristine (School of History, Classics and Archaeology, Newcastle University)

William M. Adams (Department of Geography, University of Cambridge)

\begin{abstract}
:
Despite the widespread use of spectral metaphors, the spectral quality of debates about extinction is little remarked by researchers in conservation science. In this paper we ask the question: does a sense of the spectral create the conditions for hopeful thoughts and actions about biodiversity? Does becoming 'haunted' by species loss accomplish anything? Our intervention is timely because the field of biodiversity conservation reflects the power of ghosts, haunting, and absence in framing the crisis of biodiversity loss and in the moral tales that it uses to justify urgent conservation action. These spectral ideas have power to shape the way conservationists think and act. Yet, crucially, the connections between ghosts, haunting, and conservation are not much acknowledged or discussed in conservation itself. Here, we explore the hopeful potential for conservation's ghostly engagement by drawing on the literature on the spectral turn in cultural geography.
\end{abstract}

\section{Keywords:}

Conservation, Spectral geography, Extinction, Haunting, Hope, De-extinction, Ghosts, Absence 


\section{Introduction:}

We live in a time of human-caused mass extinction and ecological crisis. It is understandable to feel a sense of dread about the future of our planet and its life forms, and to be 'haunted' by these losses. In this paper we explore the implications of a sense of the 'spectral' - of ghosts and haunting - for the way we think about conservation. Can it create the conditions for hopeful thoughts and actions with respect to biodiversity? What does becoming 'haunted' by these losses - in whatever sense of the term - accomplish? Does it enable us to think about conservation in an alternative and actionable way? In what follows we use an eclectic range of sources, drawing on conservation literature, popular science, field observation methods, and spectral theory, to clear a space for an intellectual engagement between spectral geography and conservation on the topic of species loss and potential return.

\subsection{North America's 'ghost cat'}

The Eastern cougar (Puma concolor couguar), frequently referred to as the 'ghost cat', has a long history of liminal presence in North America. It once ranged from South Carolina to Canada, but early in the colonial period it was targeted in hunting drives by so-called 'Panther Boys' who 'thought it no breach of duty to exterminate' them. ${ }^{2}$ By 1750 , it was critically endangered in the original colonies and it became an elusive and shadowy presence as settlers spread, known less by actual sightings than by a peculiar cry that travellers likened to a woman being strangled. The Eastern cougar was last conclusively recorded in Maine and New Brunswick in the 1930s, although Bruce Wright, a student of the renowned conservationist Aldo Leopold, later published two books (The Ghost of North America: The Story of the Eastern Panther 
(1959) and The Eastern Panther: A Question of Survival (1972)) that assembled extensive evidence for their continued survival.

As cougars declined in numbers, superstitions surrounding them grew: stories were told of how they returned to haunt the scene of their death; that hearing their screams was a foreboding of death; and that stuffed specimens left their plinths on All Souls' Night to wander museums in search of prey. ${ }^{3}$ The Eastern cougar's ghostly charisma was also reflected in myth and fiction, especially Charles Brockden Brown's Edgar Huntly; Or, Memoirs of a Sleepwalker (1799), a foundational novel in American Gothic literature.

The Eastern cougar was declared officially extinct by the US Fish and Wildlife Service (USFWS) in 2015 after a four year review of available evidence. However, cougar networks across the eastern states in the USA continue to collate reports, produce maps, and communicate evidence of their persistence. ${ }^{4}$ Sceptical conservationists dispute this evidence, and suggest that such sightings are actually of bobcats, large domestic cats, escaped mountain lions, or wandering Western cougars. One said - 'People often see ghosts, so maybe we're seeing ghosts of lions out there in the landscape'.

Meanwhile, in Ontario, Canada, the presence of the cougar remains contentious, with numerous reported sightings. ${ }^{6}$ The Canadian Ministry of Natural Resources did not support the USFWS decision, and the Ontario Puma Foundation estimates there to be 550 cougars across the province. ${ }^{7}$ However, in the absence of captured live animals, photographs, or specimens, the estimate was reached through sightings, scat samples, and tracks - a catalogue of ghostly signs of presence without definitive scientific proof. 


\subsection{Extinction and spectrality}

We open our discussion with this sketch of the strange absence-presence of the Eastern cougar because it encapsulates many critical themes surrounding 'ghost species'. Biodiversity conservation is obsessed with species (notwithstanding debates about hybridity and interbreeding), ${ }^{8}$ and species that are either actually, or almost, extinct, and the process of disappearing, provide an immensely powerful frame for conservation thinking and action. The idea of extinction - the death of the last individual of a species - has repeatedly been used to describe the aspirations and work of the conservation movement. ${ }^{9}$ The human-caused extinction of species such as the dodo (a flightless pigeon from the island of Mauritius), Steller's sea cow (a giant manatee from Alaska), the quagga (a subspecies of plains zebra from the African Cape) and the great auk (a flightless seabird from the north Atlantic) were cited by boosters of the infant conservation movement in the late nineteenth century as exemplars of the problem that conservation needed to address.

Since then global rates of extinction have been accelerated by human population growth, climate change, the destruction of habitats, and the consequences of importing 'invasive species'. ${ }^{10}$ Recognition of the global impact of human activities on biodiversity and ecosystems has been generalised by the Millennium Ecosystem Assessment (2005) and the notion of an 'Anthropocene' era. ${ }^{11}$ The current era is portrayed as undergoing a 'sixth mass extinction', and the 'biodiversity crisis' is, CNN announced in 2016, 'far worse than you think'. ${ }^{13}$

This situation has clear cultural implications related to death and loss. Heise notes that the genre templates of conservation stories tend to be those of elegy and tragedy, 
generating nostalgia and attempting to harness its energy to provide support for conservation causes. Conservation's morality tales of extinction, with their powerful affect of 'lament, melancholy and mourning' reflect a deep unease about the role of human society in the impoverishment of an apparently 'natural' world. ${ }^{14}$

The emotive power of the metaphor of extinction in conservation is strange in as much as it stands at odds with the scientific framing of the history of life on Earth, one of evolution and extinction on different scales - of the relentless disappearance and appearance of species. We live in a world where (according to the fossil record) some $99.9 \%$ of all the species that have ever lived are now gone, ${ }^{15}$ yet the mass vanishing of species associated with human activities in (at least) the last 500 years is not a 'natural' outcome of the normal, or background, extinction rate. While earlier mass extinctions were caused by cataclysmic geological events, it is argued that the sixth mass extinction is unusual and untimely because of our impact as global actors. ${ }^{16}$ For humans, this makes it an event that does not close off all narrative with the decomposition of the last cadaver or the declaration of extinction. Rather, extinction becomes a 'spectral' event in that a moment of death and disappearance generates lively and provocative responses These responses, as we will show, have the potential to be hopeful as well as mournful.

Despite the centrality of scientific methods to conservation accounts - for example in the process of inscribing species on the World Conservation Union's (IUCN) Red List - the extinction of species in conservation narratives is often represented through the language of disappearance, absence and haunting. Heise makes the point in also using the term 'ghost species' to describe those creatures that scientists conclude to be extinct but which continue to be reported by observers, such as the Hokkaido wolf in Japan, or the Ivory-billed woodpecker in the United States. ${ }^{17}$ This is particularly true 
of species that have gone extinct in the relatively recent past, during the era of industrialisation, and whose images are captured in photographs or on film.

Photographs like that of the 'last' living thylacine in Hobart Zoo, Tasmania, in 1936 have achieved an iconic status. Some such photographs, like 'Martha', the 'last' passenger pigeon that died in Cincinnati Zoo in 1913, were of museum specimens: when photographed Martha was already dead and stuffed. ${ }^{18}$ Conservation stories, such as those involving these photographically-preserved individuals, involve engagements with beings that are liminal and spectral in the imagination, inhabiting a borderland between visibility and invisibility. Indeed Yusoff observes 'the non-humans we encounter are predominantly spectres making virtual appearances or standing as ciphers for species': images relate to lives that are never known, and can never be completely known, even before they disappear through extinction. ${ }^{19}$

These species have generated many artistic invocations of absence that play on the idea of extinct species as ghostly or 'spectral' presences, exerting power in their absence. Numerous memorials, art projects, sound installations, and mock funerals have sought creative ways to draw attention to extinction, for example the 'Remembrance Day for Lost Species' (annually celebrated in UK and other countries on November 30), and the 'Mass Extinction Monitoring Observatory' (MEMO), a proposed stone construction on the Dorset coast. ${ }^{20}$ The publicity for the 'Ghosts of Gone Birds' exhibition in the UK in 2011 promised to mobilise a 'creative army' that would 'breathe artistic life back into extinct bird species'. ${ }^{21}$

The spectral quality of debates about extinction is little remarked by researchers in conservation science, although the titles of scholarly books and articles on the subject of extinction demonstrate the widespread use of spectral metaphors in thinking about 
species loss. ${ }^{22}$ There has, however, been interest from cultural geographers and environmental humanists in the ghostly dimensions of our relationships with animals. ${ }^{23}$ In this context, Ginn, Beisel, and Barua suggest that an important task for environmental humanists is 'to build an empirical repertoire and conceptual language that accounts for the vulnerable, absent, the unloved, and the (soon to be) disappeared'. ${ }^{24}$ They argue that the modern era of extinction creates opportunities for scholars to imagine and explore spaces of absence and disappearance. Such an approach offers 'a necessary corrective to an environmentalism too often caught between suppressing its apocalyptic despondency on the one hand and embracing a techno-managerialist optimism on the other'. ${ }^{25}$

In the rest of this paper, we respond to this call by developing an 'empirical repertoire' and 'conceptual language' to facilitate hopeful spectral geographical reflections on conservation. Our intervention is timely because the field of biodiversity conservation reflects the power of ghosts, haunting, and absence in framing the crisis of biodiversity loss and in the moral tales that it uses to justify urgent conservation action. This dual use of the spectral is important because it implies that we do something positive with the sense of dread, that we move, as Lawson put it, 'beyond fear and toward hopeful, constructive engagements with our world'. ${ }^{26}$ Spectral ideas, we argue, have the power to shape the way conservationists think and act: in response to past and present extinctions money is spent, organisations and projects are created, and land is surveyed, managed, and set aside for 'nature'. People are recruited to conservation causes by stories of past extinctions and about those predicted to occur in the future, but the hope of resurrection also haunts extinction narratives and it in turn mobilises conservationists, artists, and searchers to join campaigns. Yet, crucially, the connections between ghosts, haunting, 
and conservation action are not much acknowledged or discussed in conservation itself. Here, we explore the potential for conservation's ghostly engagement by drawing on the literature on the spectral turn in cultural geography.

\section{Spectral Geographies and Extinction}

\subsection{Ghosts and haunting}

In the past two decades, the field of spectral geographies has addressed many dimensions of the power of ghosts and haunting. As ghosts symbolise the persistence of the past, they feature routinely as actors in research on political violence, displacement and migration, urban change, and memory. ${ }^{27}$ In this literature, to be a ghost can mean being a refugee, a slave, a victim of state terror, or a missing person. Indeed, the category of missing people foregrounds spectrality by directing hopeful intentions at someone who used to be here and currently is not - but who might return some day, or be found. ${ }^{28}$ Images of the missing, particularly photographs, can have lives of their own, working as icons that evoke the living while being themselves dead.

Traditionally ghost-hunters prioritise the physical evidence of supernatural apparitions (e.g. photographs, video footage or ectoplasm). Spectral geographers, by contrast, are interested in how haunting manifests troubling presences through memories, materials, and landscapes. ${ }^{29}$ The ghost, in these understandings, is merely a sign that haunting - 'the sociality of living with ghosts' - is already taking place. ${ }^{30}$ Spectral geographies draw attention to both spatial and temporal dimensions of this everyday 
haunting. Haunting does not necessarily provide proof that something (or somebody) dead exists or persists; rather it reveals the feeling that it is missing - the absence of presence can co-exist with the presence of absence. ${ }^{31}$ In other words, absence is experienced - and can only arise - in lived experience. ${ }^{32}$

While invoked in much writing about biodiversity loss and extinction, the hauntings of lost species have not been explored much through the lens of cultural geography. This is something of a blind-spot for the discipline because extinct species (especially charismatic species) are commonly located and/or mourned in space: the last known location where they were observed becomes the place of commemoration or search (as the wetland bottomwood forests of Louisiana and Arkansas have at times through recent decades for the Ivory-billed woodpecker). ${ }^{33}$ The significance of these 'spaces of absence and disappearance, of vulnerability to violence and death' ${ }^{34}$ is clear from contemporary art projects such as Last Seen in which Lorraine Turi took photographs at the locations where extinct species were last recorded in the USA. ${ }^{35}$ Even when she finds concrete, shopping malls, or other signs of human infrastructure in these locations, Turi says 'In every place I am hopeful that I will find a lost species still there'. ${ }^{36}$

The issue of temporality is also fundamental to spectral geographies through the recognition that conventional before-after distinctions are confounded by haunting, which brings together 'distant presences, events, people and things' ${ }^{37}$ A distinction may therefore be drawn from extinctions that are known, and that are recognised as an absence, and those that can be presumed, because the lost species was never known, and is 'completely gone, erased from all memory and vanished without a trace'. ${ }^{38}$ How can absences be traced through time, particularly ones not previously known to 
exist? Absences rely on traces, documentation, and 'the defeat of all claims to presence': this represents a theoretical, methodological, and material challenge. ${ }^{39}$

\subsection{Charisma and (in)visibility}

Cultural geographical work on ghosts and haunting focuses on people, politics, and cities, but non-human animals and their environments can also appear as ghostly and monstrous. ${ }^{40}$ People's relationships with animals - extant, extinct, or mythical - are complex and can involve emotional and spiritual attachments across space and time. Companion animals are extensively loved and memorialised, in particular dogs (e.g. Greyfriars Bobby) and racehorses (e.g. Red Rum). ${ }^{41}$ In other cases, the reporting of phantom beasts reflects a more zoological search for 'hidden', mythical, or hypothesised creatures - but this is no less of an emotional relationship. We have argued elsewhere that cryptozoology - whether the hunt for big cats in the British countryside, or the search for the survivors from previous geological eras consistently excites and generates hope for scientists and adventurers. ${ }^{42}$

It is a macabre reality that death and disappearance enhances the charisma of species. Non-human charisma reflects the routine policing of absence and presence that has taken place throughout the history of nature conservation and conservationists have long recognised the peculiarity of their concern for certain threatened species, almost always animals. ${ }^{43}$ The extinct species that are known, named, and mourned, tend to be birds and mammals with memorable histories of interactions with humans. The extinct species that are evoked as storied, photographed, or archived creatures, represent a highly biased taxonomic sample. ${ }^{44}$ The alarming decline of insect biomass, meanwhile, provokes comparatively little attention among people, let alone 
commemoration. ${ }^{45}$ Selective visibility, then, is part of how conservation works and this binds it to debates about spectrality and haunting.

The disappearance of species can be sudden and mysterious: in the case of the Cretaceous-Paleogene mass extinction, this has contributed to popular fascination with the end of the dinosaurs. However for most species, disappearance is not sudden, and it reflects a politics of presence, visibility, and representation. Species disappear gradually over time, through human historical practices and policies that kill or reduce visibility and social relevance. Disappearance is a non-linear and paradoxical process in that it leaves traces, signs, clues, and can provoke recurring reappearances (sightings of Ivory-billed woodpeckers and thylacines, for instance, are frequently reported). As Gordon argues, disappearance is fundamentally 'apparitional' in that it involves the production of ghostly effects rather than a sudden vanishing. ${ }^{46}$

This ghostliness both reflects the precarious and vulnerable status of the disappeared body, and provides that body with the power of making itself and its history known through haunting and/or reappearance. 'Ghosthood', therefore, is a volatile mix of weakness and power, invisibility and visibility: it is both a given status and a potential for action. In other words, absence exerts power in the social world because it shares the same source of being as presence. One way to conceptualise the kind of condition that certain non-human bodies have in the world is through the idea of 'spectral presence' - a form of being in the world that is uncanny and at risk of vanishing.

\section{Conservation's ghost hunts}

\subsection{Ecological haunting}


In recent years a growing number of cultural geographers have argued that absences are tangible; they inspire action, trigger memories, and contextualise presences. For instance, when people engage with absences in 'ghost towns' and ruins in the US, or among undocumented immigrants in Sweden, they reveal stories and narratives involving the politics of remembrance and social injustice. ${ }^{47}$ Rather than dramatically uncovering the hidden or the missing, the power of absence to do things seems to rest in its mundane and everyday presence: absences weigh heavy. They are everywhere, if you know how to look for them. Absence is therefore relational and actionable: like the play of shadows, absences provoke the imagination and can '[structure] experience and memory’ by sending ripples through what remains present. ${ }^{48}$

Understood in this sense, absence exerts a powerful influence over conservation thinking, a power that appears to be ghostly. Aldo Leopold wrote of this power of absence/spectral presence of the jaguar (Panthera onca) in the Delta of the Colorado River:

We always examined these deer trails, hoping to find signs of the despot of the Delta, the great jaguar, el tigre. We saw neither hide nor hair of him, but his personality pervaded the wilderness, no living beast forgot his potential presence, for the price of his unwariness was death. No deer rounded a bush, or stopped to nibble pods under a mesquite tree, without a premonitory sniff for el tigre. ${ }^{49}$

For Leopold el tigre still exerted ecological power over the landscape, influencing instincts, behaviours, and human cultural memory years after its absence. The disappearance of the jaguar, in other words, was an apparitional process that did not end in any final or absolute erasure from the ecosystem. Rather the jaguar continued to resonate as a presence along the Colorado River because its ecosystems have 
processes that persisted long after the keystone carnivore became absent in the landscape.

In the same way, rewilding advocate George Monbiot suggests that the fact that British woodland shrubs readily shoot from their rootstock (usefully allowing them to be coppiced by humans) is an adaptation to the browsing of the straight-tusked elephant, Elephas antiquus, which died out in Britain over 100,000 years ago. He writes of modern humans:

we evolved in a wonderful, terrible world, of horns and tusks and fangs and claws, and we carry with us the vestigial psychological equipment - a ghost psyche required to navigate it. I believe we miss the thrill and fear the great beasts inspired, just as our ecosystems miss their interventions. ${ }^{50}$

The notion of spectrality and ghostliness is used in ecology to describe ecological relationships and processes lost with local species extinction. The 'ghosts of predators past' can remain significant long after they have disappeared. For example levels of stress hormones in a female snowshoe hare (which affects their fertility) are inherited from their own mother's exposure to predators, a curious form of intergenerational haunting. ${ }^{51}$ Such 'ghostly' effects of extinct species are not confined to animals. The lancewood tree in New Zealand is described as 'stuck in a time warp' as it is still defending itself from the moa some 500 years after the flightless bird species became extinct. $^{52}$

Ecological hauntings like this therefore suggest forms of absence that are not final, absolute, or hopeless. While the spectral presence of moas is clearly not the same as their actual presence in an ecosystem, their ghostly effects (whether sensed by plants and humans) at least provide a sense of the past as persistent and unfinished. 
Furthermore, 'ghosting', or keeping a species that biologists agree to be extinct on the endangered list, has the important outcome of sustaining strict environmental protections over an area. ${ }^{53}$ This sense of ecological haunting therefore provides grounds for hope in inspiring people to conservation action, even in the absence of the target species.

\subsection{The Red List}

A key framing device for conservationists to communicate with people about extinction is the Red List of Threatened Species, produced by the Species Survival Commission of the IUCN. The Red List provides a baseline for measuring species decline. Data gathered from a global network of experts is used to categorise species on a spectrum between absence and presence (including Extinct; Extinct in the Wild; Critically Endangered; Endangered; Vulnerable and Near Threatened, Least Concern). ${ }^{54}$.

The Red Listing process is limited both by the availability and knowledge of its experts, and the availability of data on global biodiversity. Less than $3 \%$ of known species have been assessed, with extensive knowledge of only a few taxa (particularly birds, mammals, reptiles and amphibians, and flowering plants). ${ }^{55}$ As we noted above, this reflects a tendency in conservation to give disproportionate attention to species that have charisma for us. This impacts on the threat status of well-known species, because they are less likely to disappear from the world without notice. It is a different story for species of fungi or insects that lack charisma for most people. Looked at from this perspective, the Red List is a haunted by a spectral warning: '[F]or every species listed as endangered or extinct at least a hundred more will 
probably disappear unrecorded' ${ }^{56}$ This implies categories of species that are neither detected nor missed - a ghost population akin to the 'missing missing' people (unreported missing people) that haunt societies. In other words, deciding what lifeforms count in conservation is something that involves a politics of representation, a means of making certain bodies present and others absent. ${ }^{57}$ However, just as absence from records or surveys does not necessarily mean 'not present', the designation of extinction is neither an empirical dead-end nor an analytical void, but rather something that involves and invites the hopeful sensing of presences in the environment. The key to conservation's engagement with ghosts is the huge effort put into patrolling the boundaries between presence and absence.

As Heise notes, the affective and elegiac framings of loss that are so prevalent in conservation narratives (and the Red List) stimulate a range of practices of conservation care. ${ }^{58}$ In particular, the declaration of a species as critically endangered or possibly extinct leads conservationists to a variety of actions. In 2018 the IUCN announced that the Fin Whale and Mountain Gorilla were no longer critically endangered thanks to international bans on commercial whaling and collaborative conservation efforts in central Africa. ${ }^{59}$ Species that are imagined as being closer to the boundary between absence and presence assume a spectral status in these kind of actions. In the case of thylacines, these actions have taken the form of: scientific surveys and expeditions; encouraging 'ghost-hunts' by the public; narratives of hope and mourning; and a genetic sequencing project. ${ }^{60}$

Therefore, as an 'organised project', ${ }^{61}$ conservation involves ideas and practices that focus on presence, but are actually haunted by absence. Many of conservation's concerns with survival and extinction are explicitly spatial, involving the survey and mapping of the presence or absence of species or the state of ecosystems. This 
conservation science draws heavily on the spatial technologies of remote sensing and Geographical Information Systems science in novel fields such as 'Conservation Biogeography'. ${ }^{62}$ However, these concerns are inherently spectral, in that absence drives conservation action in the form of scientific surveys and haunts these ecosystems through technologies that make absent humans remotely present (e.g., camera traps; autonomous acoustic sensors).

\subsection{Camera traps and re-presencing}

As 'ghostly technologies', camera traps have a critical importance as an essential tool for conservationists to gain knowledge of nocturnal, elusive, remotely located, or critically endangered species. ${ }^{63}$ This is because camera traps out-perform other survey methods that establish presence (e.g., scat collection; direct observation); camera traps are also advantageous in not requiring humans to be present in the environment. ${ }^{64}$ This practice discloses some features that intersect with spectral geographical themes.

The conservationists and wildlife photographers who set up these camera traps are quick to recognise in their publicity that they are engaged in something of a ghosthunt, commonly talking about glimpses of 'living ghosts'. ${ }^{65}$ Leaving aside this use of ghostly language, a very interesting oscillation between absence and presence happens at the scene of the camera trap: humans are absent and rely on technology to look from a distance. In fact the implication is that it is only by being absent, or spectrally present through the technology, that the animal will appear. Camera traps in the wild are therefore profoundly uncertain things, staged like a séance awaiting spirits, which echoes their use in the spooky castles of popular TV shows like Most Haunted. 
This ghostly power of unseen sight is something that the camera trap generates and distributes, for the camera trap is a scene about spectral watching on the part of humans: as conservationists gradually remove themselves from the scene of photography, they have become more virtually present there through networked digital cameras and live streaming. However the cameras themselves are also watched over - human scent on the cameras alerts many animal species to de facto human presence, and so they avoid the visor gaze of the hidden, camouflaged camera, thereby remaining uncaptured and unrepresented. ${ }^{66}$ Camera traps are known to affect the behaviour of animals like tigers, which may be locally present but choose to avoid camera trap sites. ${ }^{67}$ One analysis of camera trap images of radio-collared coyotes in California found that alpha pairs were under-represented, challenging the assumption of equal detectability. ${ }^{68}$ The 'visor effects' of camera trapping, as Derrida would put it, $^{69}$ oscillate between people and the species they attempt to photographically capture, demonstrating again how disappearance is never straightforward, but is always apparitional.

Camera trap photographs are of enormous value to conservationists because they inspire further conservation actions and tell stories of hope and rediscovery that resonate with people. There are 'surprise stories', as in the case of the Yellow-bellied weasel which was finally photographed in Cambodia in 2014 after 8000 hours of camera trap recordings: the failure of the weasels to present themselves to the camera lens raised, according to the research team involved, 'questions over whether the weasel is rare, or simply skilled in avoiding camera traps' ${ }^{70}$ Species like the snow leopard, star of the Planet Earth II TV series owing to camera trap footage, are almost never seen in the field by human eyes. 
The facts of field survey methods in conservation come about through practices that make species present - that is, watching, counting, calculating, and modelling. In determining whether a species exists in a particular location, science is paramount: where there is doubt, 'nothing exists until irrefutable scientific evidence for its existence is acquired by experts'. ${ }^{71}$ Some accepted scientific proof practices are controversial, such as the killing of individuals from relict populations of endangered species to provide taxonomic 'voucher specimens' (e.g. the killing of an endangered Guadalcanal moustached kingfisher in 2015). ${ }^{72}$ The problem with this is that conservation 'facts' are never settled. As Hinchliffe writes, 'the objects of conservation (like species and habitats) are not fully formed or always fully present, but in the process of being made present' ${ }^{73}$ Crucially, accurate conservation data can be undercut by the many species that remain absent from observation: out of an estimated 7-15 million species in the world only around 1.7 million have been described. ${ }^{74}$ This population constitutes part of the vibrant 'hidden' or 'dark diversity' in ecological communities. ${ }^{75}$ Not seeing disappearing species may make them disappear even more: in such situations absence clearly means something different than simply 'not present'.

Re-presencing efforts in conservation can be highly professional or based on citizen science. The science of DNA sequencing and barcoding, for instance, allows conservationists to detect invisible presences at a fine scale through survey techniques that 'census' unseen individuals. ${ }^{76}$ Meanwhile citizen-led 'bioblitzes' perform a valuable biodiversity function by taking a snapshot of life in a small area to inform conservation action. They also have a public engagement role in attracting ordinary people to conservation projects with the promise of revealing the 'secret' or 'hidden' worlds on their doorsteps. ${ }^{77}$ 
The spectrality of species, then, is not simply a theoretical premise: this condition or power stimulates expenditure and inspires social efforts to patrol the boundaries between presence and absence. Rather than ending a narrative, declaring a species to be critically endangered or extinct in the wild can actually generate huge survey efforts to establish their presence once again and tell new stories about their lives, behaviours, and the threats they face from humans. Some conservation NGOs flirt with the concept of 'ghost-hunting' to mobilise people to seek out critically endangered species and make them visible for the purposes of urgent conservation action. In 2009, for instance, BirdLife International launched a global campaign to track down 47 species of bird that have not been seen by humans for up to 184 years. This target list of 'long-lost ghosts' includes the Jamaican petrel, the hooded seedeater, and the Himalayan quail. ${ }^{78}$ In seeking to bring lost species back into presence, surveyors do not think of them as absolutely gone. Rather, their actions suggest that they have a liminal status, as if they were in the 'data deficient' category of the Red List or the 'likely presence' category that Hinchliffe proposes ${ }^{79}$ - both shadowy holding zones where animals can be imagined to still exist beyond human sight. Absence here inspires a sense of presence that calls upon our imaginations and emotions as much as on our survey techniques and camera traps.

\section{Revenant species: rediscovery and de-extinction}

Conservation has a particular concern with species that have an awkward or uncanny ontological status in the language and action of conservation. ${ }^{80}$ This typology includes creatures that hover uncertainly on the brink between absence and presence, survival 
and extinction. Thus, for example, the death of the last known male Northern white rhinoceros in a game reserve in Kenya in 2018 led to an outpouring of angst, but also to proposals for a complex, expensive, and invasive scientific procedure using gene editing, in vitro fertilisation and a surrogate parent to recreate a new male animal thus saving the sub-species. A scientist commented 'Think of the money that goes into the Premier League. It would only take a fraction of that to save a creature that we have deliberately hunted just for its horn. We have a duty to try to bring it back from the brink' ${ }^{81}$

The Northern white rhinoceros is the latest charismatic mammal to join the list of endangered or extinct species that are practically thought of as revenants in that they might return to the world in some restored form through sustained conservation action or scientific rescue. Despite the consistent criticism within conservation that many of these species and sub-species are extinct for unalterable reasons of habitat decline and that they constitute nature's 'living dead ${ }^{82}$ - optimistic narratives of return and resurrection have valuable cache in popular conservation communication.

The ultimate prize of conservation ghost-hunts is the rediscovery of a species once listed as extinct. Some such rediscoveries are mostly accidental, the fruit of routine scientific surveys (although the possibility of finding new species when remote areas are surveyed is always high, and never far from the minds of those organising such investigations). The quest to rediscover long-lost species (or 'Lazarus species', named after the Biblical story of Jesus raising Lazarus from the dead ${ }^{83}$ ) can 'provide beacons of hope in an increasingly desperate scramble to conserve species' ${ }^{84}$

Over 350 mammal, bird and amphibian species have been rediscovered since 1889, and rediscoveries are happening at an increasing rate. ${ }^{85}$ Many rediscovered species are 
instantly classified as endangered. Thus the blue-eyed ground dove Columbina cyanopsis was rediscovered in Brazil in 2015 (by an ornithologist who heard a song he did not recognise). ${ }^{86}$ Other examples of rediscoveries abound in conservation journals, from where they are picked up and circulated widely by popular science journalists. $^{87}$

Other rediscoveries are the product of individual persistence, often in the face of sustained scepticism. This was the case with the rediscovery of the night parrot (Pezoporus occidentalis) in Australia, a species considered by many to be functionally extinct because it had been only sighted a few times during the twentieth century. ${ }^{88}$ Yet in 1990 a group of ornithologists found a dead bird on the road in southwest Queensland. This roadkill was taken as a precious sign that the species still existed. It was not until 2013, however, that a live night parrot was located and photographed, generating headlines worldwide. This raised hopes that similar disappearances were apparitional rather than absolute - that other cryptic or secretive 'extinct' species still exist in the Australian wild. In presenting a journey from absence to presence, and loss to renewed hope, rediscovery stories such as this are particularly potent in reframing extinction as an uncertain inference, or even a reversible process. This has positive and negative implications for conservation. ${ }^{89}$ It is interesting that in the years before the bird was conclusively proved to be present in Queensland, a mining company was required to fund a national research plan and surveys before expanding into territory where the night parrot was rumoured to exist. ${ }^{90}$

Elsewhere conservation and ideas of resurrection meet in the nascent science of deextinction. Sometimes styled 'resurrection biology', de-extinction science promises to restore extinct species to forms of presence through cloning, synthetic biology, or 'breeding back' programs. ${ }^{91}$ This has consequences for our perceptions of time, as 
ecological ghosts return to 'haunt' the present. It also has consequences for our perceptions of place, as 'rewilding' projects seek to transform or 'restore' landscapes to ecological states that none living ever experienced. ${ }^{92}$

De-extinction can also be thought about in ecosystem terms - as driving ecosystem recovery by restoring ecological function, re-starting latent ecological processes and restore lost ecosystems or ecosystem states and functioning. This is one meaning of the term rewilding. ${ }^{93}$ As Beth Shapiro suggests, 'we should think of de-extinction not in terms of which life form we will bring back but what ecological interactions we would like to see restored'. ${ }^{94}$ De-extinction science forges new cultural and legal relationships between humans and endangered or extinct species. Some question whether a de-extincted life-form would resemble its ancestors or represent the return of a 'species' at all, given its synthetic birthing and lack of appropriate habitat. ${ }^{95}$ Therefore the key question here is not 'how hopeful should we be about deextinction?' but 'what kinds of hopeful (or dreadful) futures do de-extinction advocates envision?'.

\section{Conclusion: conservation's hopeful ghosts}

A children's activity picture book titled Invisible Endangered Animals shows a series of backdrops (jungle, mountain, river, etc.), but no animals. When the blank spaces on the pages are rubbed with a pencil, a series of endangered animals are revealed. The animals are present on the page, but until then are invisible. Their presence is disguised as absence; indeed, it is part of absence. The simple act of tracing with a pencil makes the missing creatures come 'magically to life' ${ }^{96}$ Critics have argued that there is a culture of hopelessness, grief, and despair among conservationists and that 
this impacts popular perceptions of conservation messages. ${ }^{97}$ This picture book is one simple example of how conservationist ghost stories can reflect the uncertain status of species that are going, gone, or returning. We suggest that spectral narratives like this must form part of the grand desire of some conservationists to 'un-doom the wondrous loveliness' of biodiversity. ${ }^{98}$

The missing and the maybe-gone exert considerable power within conservation programmes. A premature declaration of extinction can cause resources to be redirected elsewhere, thus dooming the critically endangered species to further losses (the 'Romeo error'). ${ }^{99}$ Furthermore, the power of absence to drain resources, energy, and goodwill should not be underestimated. The naturalist John Young reportedly spent 17,000 hours searching for the night parrot, before he photographed one in 2013. ${ }^{100}$ Chris McCarthy, a conservationist at Kejimkujik National Park in Nova Scotia, spent 10 years looking for the Eastern cougar before giving up in $2016 .^{101}$ There are, then, clear reasons to be despondent, but our task in this paper was to develop an 'empirical repertoire' and 'conceptual language' to facilitate hopeful spectral geographical reflections on conservation.

Firstly, we have shown that in conservation, absences and threatened absences have empirical consequences. The threat of extinction, and the ghostly language that comes with that, inspires conservationists to action (from surveys and camera-traps, to popular communications and spectral art projects). Money and effort can be wasted on searching for a species that is no longer extant. These searches can be misguided and ridiculous, but they can also be aspirational and hopeful. As in the case of the disputed 'rediscovery' of an Ivory-billed woodpecker in Arkansas in 2004, they can be rewarded with money, federal recovery plans, and artistic/symbolic rediscoveries of past histories of destruction. ${ }^{102}$ These forms of re-presencing allow conservationists 
to tell the kind of stories that foster an awareness of a shared (or haunted?) commons.

In other words, thinking about and taking action on ghost species has conservation value. Secondly, drawing on the critical literature on ghosts and haunting, we have developed a conceptual language that makes room for discussing ghost species. This is underpinned by two theoretical points that run through spectral geography, that disappearance is apparitional and that absence exerts power. These theoretical points also haunt the science and ideas behind ecological restoration and de-extinction. Indeed, given the attention it attracts, de-extinction represents a critical context for further debates about how absence and presence perform work in conservation and how cultural geographers might deal with the language and practice of 'bringing back the dead' in a more-than-human world.

\section{Acknowledgements}

We thank everyone who has fed our appetite for stories about ghost species, including Chris Sandbrook, Adam Searle, and Matthew Gandy. Thank you to Dydia DeLyser for her editorial guidance and to the anonymous peer reviewers whose criticism was constructive and provocative.

\section{Notes}

\footnotetext{
${ }^{2}$ H.W. Shoemaker, Extinct Pennsylvania Animals Part I: The Panther and the Wolf (Altoona, Pennsylvania: Altoona Tribune Publishing Company, 1917), p. 31; C. B. Brown, Edgar Huntly; or, Memoirs of a Sleep-Walker, II (Philadelphia: H. Maxwell, 1799), p. 41.

${ }^{3}$ Shoemaker, Extinct Pennsylvania, pp. 55-6.

${ }^{4}$ See Cougar Rewilding Foundation (http://easterncougar.org/index.htm); Eastern Puma Research Network (https://www.facebook.com/groups/113755902004034).

${ }^{5}$ Cited in B. Mann, 'Officially Extinct, Mountain Lions Still Haunt the Adirondacks', North Country Public Radio, 28 March, 2011. Accessed at
} 
https://www.northcountrypublicradio.org/news/story/17386/20110328/officially-extinct-mountainlions-still-haunt-the-adirondacks.

${ }^{6}$ R.H. Lemelin, 'Doubting Thomases and the Cougar: The Perceptions of Puma Management in Northern Ontario, Canada', Sociologia Ruralis, 49, 2009, pp. 57-69.

${ }^{7}$ S. Duggal, 'The Cougar is Out There', The Ottawa Citizen, 21 June, 2010.

${ }^{8}$ See for example S. Rutherford, 'The Anthropocene's Animal? Coywolves as Feral Cotraveler', Environment and Planning E: Nature and Space, 1(1-2), 2018, pp. 206-223; A. Fredriksen, 'Of Wildcats and Wild Cats: Troubling Species-based Conservation in the Anthropocene', Environment and Planning D: Society and Space, 34, 2016, pp. 689-705.

${ }^{9}$ See W.M. Adams, Against Extinction: The Story of Conservation (London: Earthscan, 2004); M. Barrow, Nature's Ghosts: Confronting Extinction from the Age of Jefferson to the Age of Ecology (Chicago: University of Chicago Press, 2009); U. Heise, Imagining Extinction: The Cultural Meanings of Endangered Species (Chicago: Chicago University Press, 2016).

${ }^{10}$ G. Ceballos et al, 'Accelerated Modern Human-Induced Species Losses: Entering the Sixth Mass Extinction’, Science Advances, 1(5), 2015, e1400253.

${ }^{11}$ However, this is a contested notion. See T.J. Demos Against the Anthropocene: Visual Culture and Environment Today (Berlin: Sternberg Press, 2017).

${ }^{12}$ See E. Kolbert, The Sixth Extinction: An Unnatural History (London: Bloomsbury, 2014).

13 'Vanishing', CNN, 2016. Accessed at https://edition.cnn.com/interactive/2016/12/specials/vanishing.

${ }^{14}$ Heise, Imagining Extinction, p. 34.

${ }^{15}$ D.M. Raup, Extinction: Bad Genes or Bad Luck? (New York: W.W. Norton, 1991), p. xvii.

${ }^{16}$ See, for instance, Ceballos et al, 'Accelerated'.

${ }^{17}$ Heise, Imagining Extinction, p. 38.

${ }^{18}$ See R. Ibbotson, 'Making Sense? Visual Cultures of De-extinction and the Anthropocentric Archive', Animal Studies Journal, 6, 2017, pp. 79-105.

${ }^{19}$ K. Yusoff, 'Aesthetics of Loss: Biodiversity, Banal Violence and Biotic Subjects', Transactions of the Institute of British Geographers, 37, 2012, p. 585.

${ }^{20}$ On the Remembrance Day for Lost Species see https://www.lostspeciesday.org; on the Mass Extinction Monitoring Observatory, http://www.memoproject.org.

${ }^{21}$ J. Lawrence, 'Art v Extinction - Ghosts of Gone Birds', BirdLife International, 19 May, 2011. Accessed at https://www.birdlife.org/europe-and-central-asia/news/art-v-extinction-ghosts-gone-birds.

${ }^{22}$ See, for example, Barrow, Nature's Ghosts; P.S. Algona, 'The Ghosts of Endangered Species Past: Recent Lessons at the Intersection of History and Biology', BioScience, 54, 2004, pp. 984-5.

${ }^{23}$ See T. van Dooren, Flight Ways: Life and Loss at the Edge of Extinction (New York: Columbia University Press, 2014); H. Reinert, 'Face of a Dead Bird - Notes on Grief, Spectrality and Wildlife Photography', Rhizomes, 23, 2012, n.p; B. Garlick, 'Cultural Geographies of Extinction: Animal Culture Among Ospreys', Transactions of the Institute of British Geographers, 44(2), 2019, pp. 22641.

${ }^{24}$ F. Ginn, U. Beisel, and M. Barua, 'Flourishing with Awkward Creatures: Togetherness, Vulnerability, Killing', Environmental Humanities, 4, 2014, pp. 5-6. 
${ }^{25}$ Ibid, p. 5.

${ }^{26}$ V. Lawson, 'Introduction: Geographies of Fear and Hope', Annals of the Association of American Geographers, 97(2), 2007, p. 336.

${ }^{27}$ See, for instance, A.F. Gordon, Ghostly Matters: Haunting and the Sociological Imagination (Minneapolis: University of Minnesota Press, 1997); J.F. Maddern, 'Spectres of Migration and the Ghosts of Ellis Island', cultural geographies, 15, 2008, pp. 359-81.

${ }^{28}$ H. Parr and N. Fyfe, 'Missing Geographies', Progress in Human Geography, 37, 2012, pp. 615-38.

${ }^{29}$ See D.P. McCormack, 'Remotely Sensing Affective Afterlives: The Spectral Geographies of Material Remains', Annals of the Association of American Geographers, 100, 2010, pp. 640-54; R. Busbridge, 'On Haunted Geography', Interventions: International Journal of Postcolonial Studies, 4, 2015, pp. 469-87.

${ }^{30}$ Gordon, Ghostly Matters, p. 201.

${ }^{31}$ L. Frers, 'The Matter of Absence', cultural geographies, 20, 2013, pp. 431-45.

${ }^{32}$ L. Meier, L. Frers, and E. Sigvardsdotter, 'The Importance of Absence in the Present: Practices of Remembrance and the Contestation of Absences', cultural geographies, 20, 2013, pp. 423-30.

${ }^{33}$ See Heise, Imagining Extinction, pp. 39-41.

${ }^{34}$ Ginn, Beisel, and Barua, 'Flourishing', p. 117.

${ }^{35}$ See http://lorraineturi.com/lastseen/. Accessed on 5 April, 2018.

${ }^{36}$ Cited in A.F. Wells, 'Lorraine Turi: The States Project: North Carolina', Lenscratch, 19 November, 2017. Accessed at http://lenscratch.com/2017/11/lorraine-turi-the-states-project-north-carolina.

${ }^{37}$ Maddern and Adey, 'Editorial', p. 292.

${ }^{38}$ Meier, Frers, and Sigvardsdotter, 'The Importance of Absence', p. 426.

${ }^{39}$ D. DeLyser, 'Tracing Absence: Enduring Methods, Empirical Research and a Quest for the first Neon Sign in America', Area, 46, 2014, p. 42.

${ }^{40}$ See J. Holloway, 'On the Spaces and Movement of Monsters: The Itinerant Crossings of Gef the Talking Mongoose', cultural geographies, 24, 2017, pp. 21-41.

${ }^{41}$ P. Howell, 'A Place for the Animal Dead: Pets, Pet Cemeteries and Animal Ethics in Late Victorian Britain', Ethics, Place \& Environment, 5, 2002, pp. 5-22.

${ }^{42}$ B. Adams and S. McCorristine, 'How the Search for Mythical Monsters Can Help Conservation in the Real World', The Conversation, 30 July, 2017. Accessed at http://theconversation.com/how-thesearch-for-mythical-monsters-can-help-conservation-in-the-real-world-81769.

${ }^{43}$ See J. Lorimer, 'Nonhuman Charisma', Environment and Planning D: Society and Space, 25, 2007, pp. 911-32.

${ }^{44}$ J.A. Clark and R.M. May, 'Taxonomic Bias in Conservation Research', Science, 297, 2002, pp. 1912.

${ }^{45}$ C.A. Hallmann et al, 'More than 75 percent Decline over 27 years in Total Flying Insect Biomass in Protected Areas', PLoS ONE, 12(10), 2017, e0185809.

${ }^{46}$ Gordon, Ghostly Matters, p. 63. 
${ }^{47}$ See Meier, Frers, and Sigvardsdotter, 'The Importance of Absence'; D. DeLyser, 'When Less is More: Absence and Landscape in a California Ghost Town', in P.C. Adams, S. Hoelscher, and K.E. Till (eds.), Textures of Place: Exploring Humanitist Geographies (Minneapolis and London: University of Minnesota Press, 2001), pp. 24-40; C. DeSilvey, 'Observed Decay: Telling Stories with Mutable Things', Journal of Material Culture, 11(3), 2006, pp. 318-38; E. Sigvardsdotter, 'Presenting Absent Bodies: Undocumented Persons Coping and Resisting in Sweden', cultural geographies, 20(4), 2013, pp. 523-39.

${ }^{48}$ DeLyser, 'When Less is More', p. 27.

${ }^{49}$ A. Leopold, A Sand County Almanac: With Essays on Conservation from Round River (New York: Ballantine Books, 1970), pp. 151-2.

${ }^{50}$ G. Monbiot, 'Thinking Like an Elephant', 15 June, 2015. Accessed at http://www.monbiot.com/2015/06/15/thinking-like-an-elephant.

${ }^{51}$ M.J. Sheriff, C.J. Krebs and R. Boonstra, 'The Ghosts of Predators Past: Population Cycles and the Role of Maternal Programming under Fluctuating Predation Risk', Ecology, 91, 2010, pp. 2983-94.

${ }^{52}$ M. Torrice, 'New Zealand Tree Stuck in Time Warp', Science, 325, 2009, n.p.

${ }^{53}$ D. Sabin, 'The Endangered Species List is Full of Ghosts', Popular Science, 25 February, 2019. Accesssed at https://www.popsci.com/extinct-species-still-on-endangered-list.

${ }^{54}$ Heise, Imagining Extinction.

${ }^{55}$ A.S.L. Rodrigues et al, 'The Value of the IUCN Red List for Conservation', TRENDS in Ecology and Evolution, 21, 2006, pp. 71-6.

${ }^{56}$ Wilcox cited in Van Dooren, Flight Ways, p.7.

${ }^{57}$ S. Hinchliffe, 'Reconstituting Nature Conservation: Towards a Careful Political Ecology', Geoforum, 39, 2008, p. 90.

${ }^{58}$ Heise, Imagining Extinction, p. 62.

59 'Fin Whale, Mountain Gorilla Recovering Thanks to Conservation Action - IUCN Red List', IUCN News, 14 November, 2018. Accessed at https://www.iucn.org/news/species/201811/fin-whale$\underline{\text { mountain-gorilla-recovering-thanks-conservation-action-iucn-red-list }}$

${ }^{60}$ See D. Jørgensen, 'Presence of Absence, Absence of Presence, and Extinction Narratives', in L. Head et al (eds), Nature, Temporality and Environmental Management: Scandinavian and Australian Pers. pectives on Landscapes and Peoples (London: Routledge, 2016), pp. 45-58; J. Pickrell, 'Return of the Living Thylacine', Cosmos, 4 July, 2018. Accessed at https://cosmosmagazine.com/biology/return-of-the-living-thylacine

${ }^{61}$ I. MacDonald, 'Business, Biodiversity and "New Fields" of Conservation: The World Conservation Congress and the Renegotiation of Organisational Order', Conservation and Society, 8, 2010, pp. 25675.

${ }^{62}$ R.J. Whittaker et al, 'Conservation Biogeography: Assessment and Prospect', Diversity and Distributions, 11, 2005, pp. 3-23.

${ }^{63}$ J. McCallum, 'Changing Use of Camera Traps in Mammalian Field Research: Habitats, Taxa and Study Types', Mammal Review, 43(3), 2013, pp. 196-206. 
${ }^{64}$ Sunarto et al., 'Camera Trapping for the Study and Conservation of Tropical Carnivores', The Raffles Bulletin of Zoology, 28, 2013, pp. 21-42.

${ }^{65}$ A. Popescu, 'What to Know Before Tracking Snow Leopards at 13,000 Feet', Bloomberg, 1 May, 2018. Accessed at https://www.bloomberg.com/news/features/2018-05-01/what-to-know-before-yougo-tracking-snow-leopards-at-13-000-feet.

${ }^{66}$ P.D. Meek et al, 'Camera Traps can be Heard and Seen by Animals', PLoS ONE, 9(10), 2014, e110832.

${ }^{67}$ P. Wegge, C.P. Pokheral, and S.R. Jnawali, 'Effects of Trapping Effort and Trap Shyness on Estimates of Tiger Abundance from Camera Trap Studies’, Animal Conservation, 7(3), 2004, pp. 2516.

${ }^{68}$ E.S. Larrucea et al., 'Cameras, Coyotes, and the Assumption of Equal Detectability', Journal of Wildlife Management, 71(5), 2007, pp. 1682-9.

${ }^{69}$ J. Derrida, Specters of Marx: The State of the Debt, the Work of Mourning and the New International, P. Kamuf trans. (New York and London: Routledge, 2006), p. 6.

${ }^{70}$ A. Ludtke, 'Yellow-bellied Weasel Spotted in Cambodia', Khmer Times, 28 August, 2014.

${ }^{71}$ Lemelin, 'Doubting Thomases'.

${ }^{72}$ S. Kaplan and J.W. Moyer, 'Scientist Under Attack after he Kills Bird that took Decades to Find', Guardian, 17 October, 2015.

${ }^{73}$ Hinchliffe, 'Reconstituting Nature Conservation', p. 89.

${ }^{74}$ G.M. Mace, 'The Role of Taxonomy in Species Conservation', Philosophical Transactions of the Royal Society of London B: Biological Sciences, 359, 2004, pp. 711-9.

${ }^{75}$ M. Pärtel, 'Community Ecology of Absent Species: Hidden and Dark Diversity', Journal of Vegetation Science, 25, 2014, pp. 1154-9.

${ }^{76}$ H.D. Loxdale, B.J. Davis, and R.A. Davis, 'Known Knowns and Unknowns in Biology', Biological Journal of the Linnean Society, 117, 2006, p. 387.

${ }^{77}$ See K. Gruber, 'People Power Unearths a Hidden World in WA [Western Australia] Soils', Ecos Magazine, 2014. Accessed at http://www.ecosmagazine.com/print/EC14211.htm.

${ }^{78}$ B. Nelson, 'Quest for 47 Species of "Extinct" Birds is Launched', https://www.mnn.com/earthmatters/wilderness-resources/stories/quest-for-47-species-of-extinct-birds-is-launched..

${ }^{79}$ Ibid.

${ }^{80}$ See J. Lorimer, 'On Auks and Awkwardness', Environmental Humanities, 4, 2014, pp. 195-205.

${ }^{81}$ R. McKie, 'How IVF and Stem Cell Science could save the Northern White Rhino from Extinction', The Observer, 25 March, 2018.

${ }^{82}$ D. Tilman, 'Habitat Destruction and the Extinction Debt', Nature, 371, 1994, pp. 65-6; J. Gilchrist, 'The Northern White Rhino Should Not be Brought Back to Life', The Conversation, 5 April, 2018. Accessed at https://theconversation.com/the-northern-white-rhino-should-not-be-brought-back-to-life94153.

${ }^{83}$ M.R. Dawson, L. Marivaux, C.K. Li, K.C. Beard, G. Métais, 'Laonastes and the "Lazarus effect" in Recent Mammals', Science, 311, 2006, pp. 1456-8. 
${ }^{84}$ D.M. Watson and R.A. Davis, 'Hopeful Monsters - In Defence of Quests to Rediscover Long-Lost Species', Conservation Letters, 10(4), 2017, p. 382.

${ }^{85}$ Ibid.

${ }^{86}$ A. Jenner, 'Lost and Found: Brazil's Blue-eyed "Ghost Species”, Discover Magazine, 25 May, 2016. Accessed at http://blogs.discovermagazine.com/d-brief/2016/05/25/blue-eyed-ground-doverediscovered.

${ }^{87}$ See for example L. Gentle, 'Meet the Lazarus Creatures - Six Species We Thought Were Extinct, but Aren't', The Conversation, 6 November, 2015. Accessed at https://theconversation.com/meet-thelazarus-creatures-six-species-we-thought-were-extinct-but-arent-50274.

${ }^{88}$ S. Garnett eds., Threatened and Extinct Birds of Australia (Moonee Ponds: Royal Australasian Ornithologists Union, 1992), p. 97.

${ }^{89}$ See D.A. Poling and E.M. Evans, 'Are Dinosaurs the Rule or the Exception?: Developing Concepts of Death and Extinction', Cognitive Development, 19(3), 2004, pp. 363-83.

${ }^{90}$ R. Davis, 'Still Here: Night Parrot Rediscovery in WA Raises Questions for Mining', The Conversation, 29 March, 2017. Accessed at https://theconversation.com/still-here-night-parrotrediscovery-in-wa-raises-questions-for-mining-75384.

${ }^{91}$ See J. Lorimer and C. Driessen, 'Wild Experiments at the Oostvardeersplassen: Rethinking Environmentalism for the Anthropocene', Transactions of the Institute of British Geographers, 39(2), 2014,pp. 169-181.

${ }^{92}$ P.S. Alagona, J. Sandlos, and Y.F. Wiersma, 'Past Imperfect: Using Historical Ecology and Baseline Data for Conservation and Restoration Projects in North America', Environmental Philosophy, 9, 2012, pp. $49-70$.

${ }^{93}$ The other being the reintroduction of large gazing and predatory mammals and avian predators. For a discussion of the term see J. Lorimer et al, 'Rewilding: Science, Practice, and Politics', Annual Review of Environment and Resources, 40, 2015, pp. 39-62.

${ }^{94}$ B. Shapiro, How to Clone a Mammoth: The Science of De-extinction (Princeton, New Jersey: Princeton University Press, 2015), p. 131.

${ }^{95}$ D.E. Blockstein, 'We Can't Bring Back the Passenger Pigeon: The Ethics of Deception around Deextinction', Ethics, Policy \& Environment, 20, 2017, pp. 33-7.

${ }^{96}$ P. Stewart, Invisible Endangered Animals (Mineola, New York: Dover Publications, 2001), back cover.

${ }^{97}$ R.R. Swaisgood and J.K. Sheppard, 'The Culture of Conservation Biologists: Show Me the Hope!', BioScience, 60(8), 2010, pp. 626-30; A. Balmford, Wild Hope: On the Front Lines of Conservation Success (Chicago and London: University of Chicago Press, 2012).

${ }^{98}$ J.D. Lanham, 'Forever Gone', Orion Magazine, 2018. Accessed at https://orionmagazine.org/article/forever-gone.

${ }^{99}$ T.M. Rout, D. Heinze, and M.A. McCarthy, 'Optimal Allocation of Conservation Resources to Species that may be Extinct'. Conservation Biology, 24(4), 2010, pp. 1111-8.

${ }^{100}$ M. Slezak, 'Australian Night Parrot Legend Lives on but Bird Remains as Elusive as ever', The Guardian, 16 April, 2016.

101 'Researcher Spent 10 Years in Nova Scotia's Forests Waiting for Ghost Cougar to Appear. Now He's Calling it Quits', National Post, 28 April, 2016. 
102 J.A. Jackson, 'Ghost Bird - The Ivory-billed Woodpecker: Hopes, Dreams, and Reality', PLoS Biology, 8(8), 2010, e1000459; Jørgensen, 'Presence of Absence, Absence of Presence'.

\section{Author biographies}

Shane McCorristine is an interdisciplinary historian whose research interests span Victorian supernatural cultures, the histories of polar exploration, the trade in human remains, and the social history of dreaming. He is a Lecturer in Modern British History at Newcastle University.

Bill Adams is a geographer whose work has ranged widely across questions of nature and sustainability. He is the author of Wasting the Rain (1992), Future Nature (1995), Against Extinction (2004) and Green Development (4th edition in press). He. $\mathrm{He}$ is Moran Professor of Conservation and Development at the University of Cambridge 